Jurnal Ilmu-Ilmu Peternakan 25 (2): 20 - 27

ISSN: 0852-3581

E-ISSN: 9772443D76DD3

CFakultas Peternakan UB, http://jiip.ub.ac.id/

\title{
Hubungan antara konsumsi protein dengan produksi, protein dan lak- tosa susu kambing Peranakan Ettawa
}

\author{
Galuh Estu Prihatminingsih, Agung Purnomoadi dan Dian Wahyu Harjanti \\ Fakultas Peternakan dan Pertanian Universitas Diponegoro, Semarang \\ dianharjanti@undip.ac.id
}

\begin{abstract}
The study aimed to determine a correlation between crude protein intake, milk production, milk protein and milk lactose. This study used purposive sampling method. The sample used in this study were 35 Etawa crossbred goats with months of lactation 4-5 and lactation periods 2-3. Parameters observed were crude protein intake, milk production, milk protein and milk lactose. Data were analyzed using correlation analysis and simple linear regression. The result showed that crude protein intake, total milk production concentrations of milk protein and lactose were $0.77 \mathrm{~kg} / \mathrm{day} ; 0.30$ $\mathrm{kg} /$ day; $0.196 \%$ and $3.32 \%$ respectively. There was a medium positive linear correlation between the crude protein intake with total milk production, protein and lactose content of milk. The correlation coefficient (r) were $0.258 ; 0.254$ and 0,255 respectively. It could be concluded that the higher crude protein intake would increase the amount of milk production, protein and lactose contents.
\end{abstract}

Keywords: crude protein intake, total milk production, milk protein, milk lactose

\section{PENDAHULUAN}

Protein merupakan salah satu komponen penentu kualitas susu. Protein kasar (PK) memiliki peran dalam pembentukan protein susu. Menurut McDonald et al., (2011), protein yang dicerna di usus halus akan menghasilkan asam-asam amino yang diserap oleh darah dan dibawa ke hati, selanjutnya oleh darah disalurkan ke jaringan tubuh salah satunya kelenjar susu untuk membentuk protein susu. Produksi susu dipengaruhi oleh beberapa faktor salah satunya yaitu faktor pakan (Herawati, 2003). Pada ternak kambing perah belum ada data yang menunjukkan bahwa meningkatnya konsumsi PK juga meningkatkan kandungan protein susu.

Laktosa susu merupakan komponen susu yang sebagian besar diben- tuk oleh karbohidrat yaitu oleh komponen glukosa dan galaktosa. Yusuf (2014) berpendapat bahwa pada saat energi ransum yang berupa karbohidrat dan lemak tidak mencukupi, maka sebagian dari asam amino akan diubah menjadi glukosa melalui proses glukoneogenesis. Protein pakan juga berperan dalam pembentukan enzim laktosa sintetase yang digunakan dalam pembentukan laktosa susu. Menurut Larson $\left(1985^{\mathrm{a}}\right)$, enzim laktosa sintetase disusun oleh galaktosil transferase dan $\alpha$ laktalbumin yang merupakan komponen protein susu. Laktosa susu merupakan komponen yang berpengaruh terhadap jumlah produksi susu. Santosa dkk (2009) menyatakan bahwa meningkatnya produksi susu disebabkan oleh sifat laktosa yang mengikat air sehingga semakin banyak laktosa yang disintesis 
maka semakin meningkat pula jumlah produksi susu.

Tujuan penelitian adalah untuk mengetahui hubungan antara konsumsi PK dengan jumlah produksi susu, kadar protein dan laktosa susu pada kambing Peranakan Ettawa (PE). Manfaat penelitian adalah diperolehnya rumus pendugaan sehingga dapat membantu peternak dalam menghitung estimasi jumlah produksi susu, kadar protein dan laktosa susu kambing PE berdasarkan konsumsi PK.

\section{MATERI DAN METODE}

Penelitian yang mengkaji hubungan antara konsumsi protein dengan produksi, kadar protein dan laktosa susu kambing PE laktasi dilaksanakan di Kecamatan Turi, Kabupaten Sleman, Yogyakarta mulai bulan November sampai dengan bulan Januari 2015.

Materi yang digunakan dalam penelitian yaitu 35 ekor kambing PE laktasi dengan periode laktasi 2-3 dan bulan laktasi 4-5. Pakan yang digunakan berupa hijauan dan konsentrat. Peralatan yang digunakan dalam penelitian yaitu timbangan gantung (Fivegoats) kapasitas $50 \mathrm{~kg}$ dengan kepekaan 0,2 $\mathrm{kg}$ untuk menimbang pemberian pakan hijauan, timbangan merk Camry EK 5055 dengan kapasitas $5 \mathrm{~kg}$ dan kepekaan 0,001 kg yang digunakan untuk menimbang pemberian dan sisa pakan, gelas ukur plastik kapasitas $500 \mathrm{ml}$ dan $1 \mathrm{~L}$ untuk mengukur produksi susu, botol sampel ukuran 100 ml untuk menampung sampel susu, freezer dengan suhu $-18^{\circ} \mathrm{C}$ untuk menampung sampel susu sementara, coolbox untuk menyimpan botol sampel susu sementara selama perjalanan menuju laboratorium, serta kantong plastik untuk menampung sampel pakan dan sampel feses.

Tahap penelitian diawali dengan melakukan survei pada seluruh peternakan di Kecamatan Turi. Hasil survei diketahui terdapat 8 peternakan dengan frekuensi pemerahan yang berbeda, sehingga dipilih 2 peternakan dengan frekuensi pemerahan yang sama yaitu 2 kali sehari dan menggunakan pakan yang seragam yaitu hijauan yang terdiri dari daun kaliandra, daun gamal, daun Indigofera dan rumput odot. Campuran konsentrat untuk ternak terdiri dari wheat bran, kedelai, mollases, jinten, garam, vitamin dan mineral.

Penentuan kambing PE yang akan digunakan sebagai materi penelitian yaitu kambing PE dengan periode laktasi ke 2-3 dan bulan laktasi ke 4-5 sebanyak 35 ekor. Kriteria lain yang digunakan dalam pemilihan ternak yaitu memilih kambing yang sistem pemerahannya sebanyak 2 kali sehari. Penentuan sampel penelitian menggunakan teknik judgement sampling dan purposive sampling.

Data yang diperoleh akan dianalisis menggunakan analisis regresi linier sederhana dan korelasi dengan bantuan program SPSS 16.0. Parameter yang diamati dalam penelitian ini adalah jumlah produksi susu, konsumsi PK, kandungan protein dan laktosa susu.

\section{HASIL DAN PEMBAHASAN}

Hasil analisis dan perhitungan bobot badan, konsumsi protein kasar, protein susu dan laktosa susu ditampilkan pada Tabel 1. 
Tabel 1. Hasil analisis dan perhitungan bobot badan, konsumsi protein kasar, protein susu dan laktosa susu

\begin{tabular}{lc}
\hline \multicolumn{1}{c}{ Parameter } & Hasil \\
\hline Bobot badan (kg) & $51,10 \pm 8,518$ \\
Konsumsi bahan kering (kg) & $3,62 \pm 0,108$ \\
Kadar protein kasar (\%) & $21,17 \pm 0,279$ \\
Konsumsi protein kasar (kg) & $0,77 \pm 0,026$ \\
Produksi susu (1) & $0,30 \pm 0,139$ \\
Produksi susu (kg) & $0,30 \pm 0,143$ \\
Protein susu (\%) & $3,50 \pm 0,196$ \\
Protein susu (kg) & $0,01 \pm 0,005$ \\
Laktosa susu (\%) & $3,32 \pm 0,184$ \\
Laktosa susu (kg) & $0,01 \pm 0,005$ \\
\hline
\end{tabular}

Berdasarkan data pada Tabel 1 diperoleh hasil bahwa rataan estimasi bobot badan ternak kambing ebesar $51,10 \mathrm{~kg}$. Konsumsi PK dan BK yang diperoleh sebesar $0,77 \mathrm{~kg} / \mathrm{ekor} / \mathrm{hari}$ dan 3,62 kg/ekor/hari. Konsumsi PK dan BK tersebut lebih tinggi daripada hasil penelitian Marwah dkk (2010) yaitu dengan rata-rata bobot badan $52,25 \mathrm{~kg}$ konsumsi PK kambing sebesar 0,34 $\mathrm{kg} / \mathrm{ekor} /$ hari dan konsumsi BK 1,86 kg/ekor/hari. Tingginya konsumsi PK pada penelitian ini dapat dipengaruhi oleh konsumsi BK yang cukup tinggi. Konsumsi tersebut dapat dipengaruhi oleh jenis pakan yang diberikan dan frekuensi pemberian pakan sehingga mempengaruhi banyaknya pakan yang dikonsumsi ternak.

Berdasarkan data pada Tabel 1 diperoleh hasil rataan jumlah produksi susu kambing PE yaitu 0,30 1/ekor/hari. Produksi susu kambing tersebut lebih rendah dibandingkan dengan hasil penelitian Marwah dkk (2010) dimana rerata produksi susu adalah 1,128 1/hari. Rendahnya produksi tersebut dapat dipengaruhi oleh bulan laktasi kambing pada penelitian ini yang sudah memasuki akhir laktasi yaitu bulan ke 4-5. Pada penelitian Marwah dkk (2010), kambing yang digunakan sedang dalam keadaan bunting dengan kisaran PK pakan 17,45 - 22,84\%.
Menurut Sidik (2003), faktor yang mempengaruhi kualitas dan produksi susu antara lain bangsa, bulan laktasi, masa laktasi dan kualitas pakan. Devendra dan Burn (1994) menyatakan bahwa kambing perah mengalami puncak produksi susu pada hari ke 4872 setelah beranak.

Rata-rata kadar protein susu yang diperoleh sebesar 3,50\%. Hal ini sesuai dengan pendapat Arora et al. (2013) yang menyatakan bahwa protein dalam susu kambing berkisar antara 3$4,5 \%$, namun rataan protein susu tersebut lebih rendah dari penelitian Adriani dkk (2014) yaitu sebesar 4,57\%. Hasil tersebut lebih tinggi jika dibandingkan dengan hasil penelitian Sukarini (2006) yaitu sebesar $2,92 \%$. Rataan tersebut dapat dipengaruhi oleh banyaknya protein pakan serta kualitas dari bahan pakan yang dikonsumsi oleh kambing sehingga asam amino bebas dalam darah semakin banyak. Semakin banyak asam amino bebas dalam darah maka prekusor pembentuk protein susu yang berasal dari pakan juga semakin banyak. Hal ini sesuai dengan pendapat Wikantadi (1977) yang menyatakan bahwa asam-asam amino bebas yang akan digunakan untuk sintesa protein susu diperoleh dari darah yang diserap oleh kelenjar susu. Faktor lain yang dapat mempengaruhi yaitu bulan laktasi 
kambing, kualitas pakan dan kandungan protein dalam pakan. Ditambahkan oleh Larson $\left(1985^{\mathrm{b}}\right)$ bahwa kandungan protein susu bervariasi tergantung dari bangsa, produksi susu, tingkat laktasi, kualitas dan kuantitas pakan serta kandungan protein dalam ransum.

Hasil pada Tabel 1 memperlihatkan bahwa laktosa susu yang diproduksi oleh ternak sebesar 3,315\%. Rataan tersebut dapat dipengaruhi oleh konsumsi karbohidrat pakan yang sebesar 2,404 kg. Selain itu juga dipengaruhi oleh banyaknya protein pakan yang dikonsumsi ternak. Protein pakan dapat membentuk glukosa melalui proses glu- koneogenesis dimana sumber utama glukosa merupakan prekusor laktosa. Menurut Bath et al. (1985), sumber glukosa yang lain yaitu berasal dari degradasi protein melalui proses glukoneogenesis.

\section{Hubungan antara konsumsi protein dengan produksi susu}

Hubungan antara konsumsi protein kasar dengan produksi susu diperoleh kurva linier dengan persamaan garis yaitu $\mathrm{Y}=1,40 \mathrm{X}-0,77$. Persamaan garis tersebut dapat digambarkan pada Gambar 1.

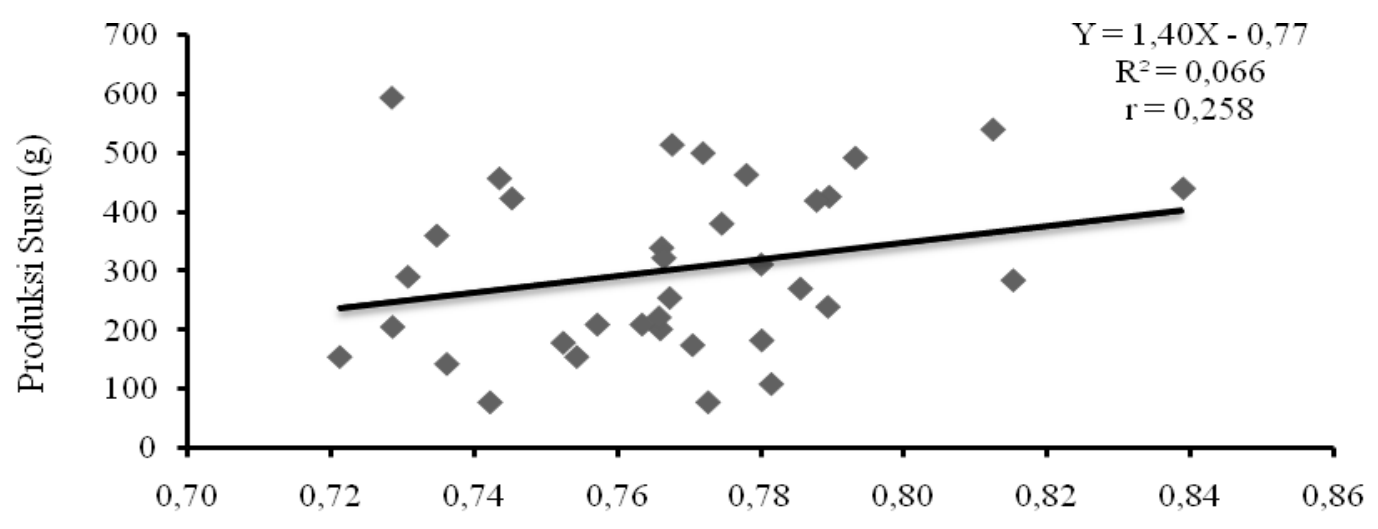

Konsumsi Protein (kg)

Gambar 1. Persamaan garis regresi linier hubungan antara konsumsi protein dengan produksi susu

Gambar 1 menjelaskan bahwa nilai koefisien korelasi (r) yang diperoleh sebesar 0,258. Hal ini menunjukkan bahwa hubungan keeratan antara konsumsi protein dengan produksi susu dalam tingkatan sedang. Sedangkan nilai koefisien determinasi $\left(\mathrm{R}^{2}\right)$ yang diperoleh yaitu 0,066 . Berdasarkan nilai koefisien determinasi tersebut menunjukkan bahwa 6,6\% konsumsi PK berpengaruh terhadap produksi susu. Produksi susu kambing tersebut selain dipengaruhi oleh faktor pakan juga dapat dipengaruhi oleh kondisi ternak, umur ternak, bulan laktasi dan frekuensi pemerahan. Frekuensi pemerahan yang dilakukan oleh peternak sebanyak 2 kali sehari. Hal ini sesuai dengan pendapat Syarief dan Sumoprastowo (1990) yang menyatakan bahwa faktor yang mempengaruhi produksi ternak antara lain umur, kondisi ternak, pakan yang diberikan, birahi, genetik, pemerah susu, interval, frekuensi pemerahan dan kesehatan ternak.

Hubungan antara konsumsi protein dengan produksi susu menunjukkan hubungan linier yang positif, artinya semakin tinggi konsumsi protein semakin tinggi pula produksi susu. 
Hubungan antara konsumsi protein dengan protein susu

Berdasarkan pada perhitungan analisis regresi linier diperoleh hasil berupa persamaan garis dari hubungan antara konsumsi protein dengan protein susu yaitu $Y=0,046 X-0,025$. Persamaan garis dapat digambarkan pada Gambar 2.

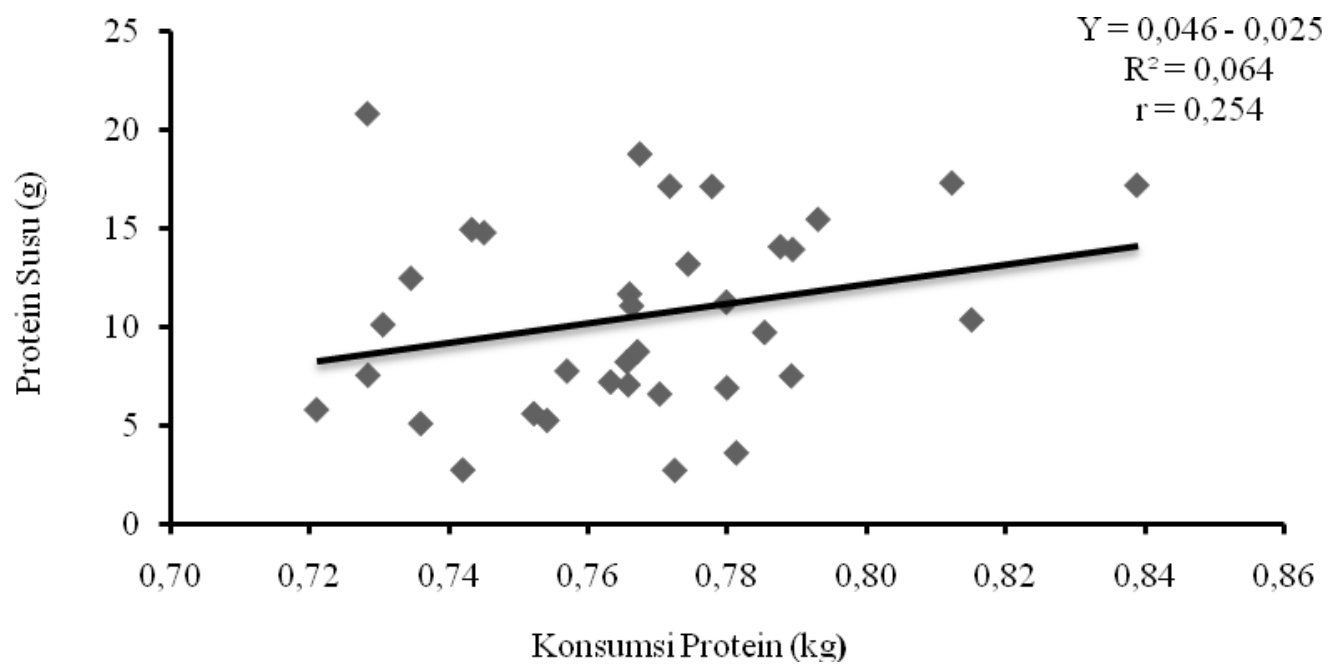

Gambar 2. Persamaan garis regresi linier hubungan antara konsumsi protein dengan protein susu

Keeratan hubungan antara konsumsi protein dengan kandungan protein susu yang dihasilkan dapat dilihat melalui nilai koefisien korelasinya (r) yaitu sebesar 0,254. Artinya nilai korelasi antara konsumsi protein dengan kandungan protein susu mempunyai hubungan keeratan yang sedang. Nilai koefisien determinasi $\left(\mathrm{R}^{2}\right)$ yang diperoleh sebesar 0,064 yang berarti 6,4\% konsumsi protein pakan berpengaruh pada tingginya kadar protein susu, sedangkan sisanya dapat dipengaruhi oleh faktor lain misalnya genetik, kondisi ternak dan lingkungan. Peningkatan kadar protein susu dipengaruhi oleh konsumsi PK karena PK merupakan prekusor terbentuknya protein susu sehingga ketika konsumsi PK meningkat akan diikuti peningkatan kadar protein susu. Hal ini sesuai dengan pendapat Larson (1985 $)$ bahwa kandungan protein susu bervariasi tergantung dari bangsa, produksi susu, tingkat laktasi, kualitas dan kuantitas pakan serta kandungan protein dalam ransum.

Hubungan antara konsumsi PK dan kadar protein susu menunjukkan hubungan linier yang positif yang artinya semakin tinggi konsumsi PK maka semakin tinggi pula kadar protein susu.

\section{Hubungan antara konsumsi protein dengan laktosa susu}

Berdasarkan pada perhitungan analisis regresi linier diperoleh hasil berupa persamaan garis dari hubungan antara konsumsi protein dengan laktosa susu yaitu $\mathrm{Y}=0,045 \mathrm{X}-0,024$. Persamaan garis tersebut dapat digambarkan pada Gambar 3. 


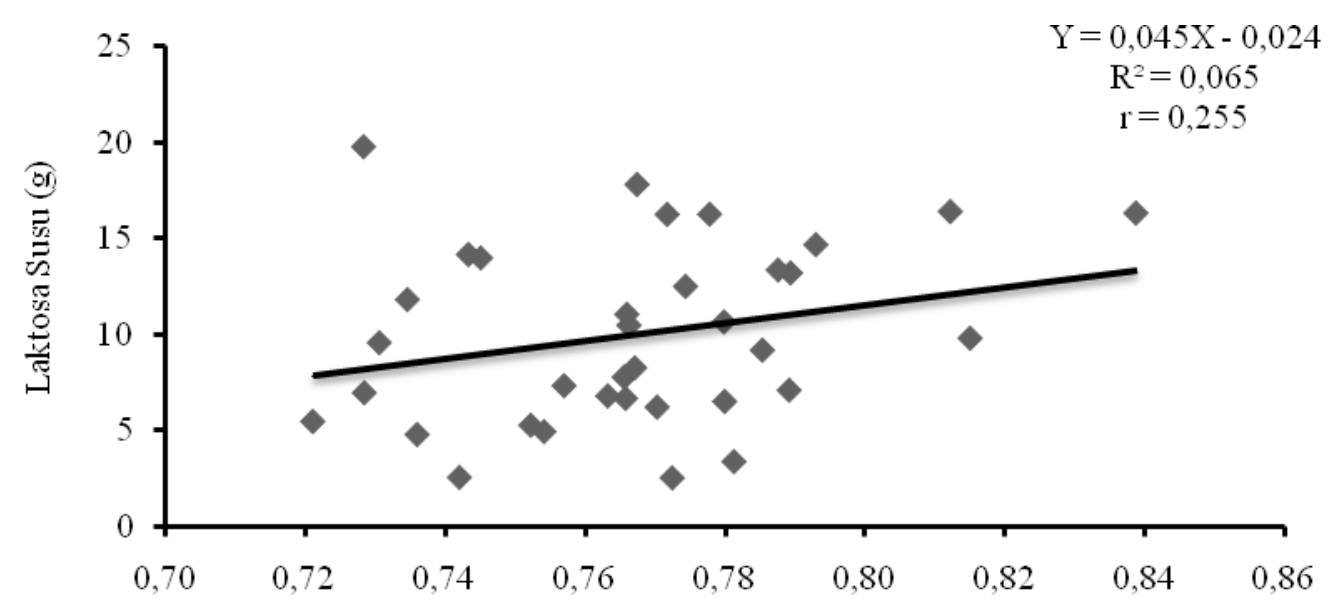

Konsumsi Protein (kg)

Gambar 3. Persamaan garis regresi linier hubungan antara konsumsi protein dengan laktosa susu

Keeratan hubungan antara konsumsi protein dengan kandungan laktosa susu yang dihasilkan dapat dilihat melalui nilai koefisien korelasinya (r) yaitu sebesar 0,255 . Nilai korelasi antara konsumsi protein dengan kandungan laktosa susu mempunyai hubungan keeratan yang sedang. Nilai koefisien determinasi $\left(\mathrm{R}^{2}\right)$ sebesar 0,07 yang berarti $7 \%$ konsumsi protein pakan berpengaruh pada banyaknya kandungan laktosa susu, sedangkan sisanya dapat dipengaruhi oleh faktor lain misalnya genetik, kondisi ternak dan lingkungan. Kandungan laktosa tersebut selain dipengaruhi pakan, dapat juga disebabkan oleh bulan laktasi ternak yang sudah memasuki akhir masa laktasi dimana pada masa tersebut kandungan laktosa menurun. Alasan ini sesuai dengan pendapat Sidik (2003) yang menyatakan bahwa faktor yang mempengaruhi kualitas dan produksi susu adalah bangsa, bulan laktasi, masa laktasi dan kualitas pakan.

Glukosa merupakan komponen pembentuk laktosa. Glukosa yang utama diperoleh dari karbohidrat pakan, namun protein pakan dapat membentuk glukosa melalui proses glukoneogenesis. Melalui proses glukoneogenesis tersebut, asam amino diubah menjadi glukosa, seperti yang disampaikan oleh Bath et al. (1985) bahwa sumber glukosa yang lain berasal dari degradasi protein melalui proses glukoneogenesis. Glukoneogenesis adalah proses pembentukan glukosa dari sumber selain komponen non karbohidrat, misalnya protein (Soebarinoto dkk, 1991). Glukosa dapat dibentuk dari sebagian asam amino. Pada ternak yang diberi pakan karbohidrat sedikit atau pada saat ternak mengalami kondisi lapar, sumber glukosa utama berasal dari glukoneogenesis yaitu lebih dari $90 \%$.

Laktosa susu dibentuk dari glukosa yang berasal dari karbohidrat dimana asam propionat diubah menjadi glukosa didalam hati. Bath et al. (1985) menyatakan bahwa fermentasi karbohidrat didalam rumen menghasilkan VFA, salah satunya yaitu asam propionat yang diubah 
menjadi glukosa di dalam hati. Peran protein pakan yang lain yaitu dalam pembentukan enzim laktosa sintetase. Pada protein terdapat komponen $\alpha$-laktalbumin yang menyusun enzim laktosa sintetase. Enzim laktosa sintetase tersebut berperan dalam pembentukan laktosa susu. Hal ini sesuai dengan pendapat Larson $\left(1985^{b}\right)$ bahwa enzim laktosa sintetase disusun oleh galaktosil transferase dan $\alpha$-laktalbumin yang merupakan komponen protein yang terdapat dalam susu.

Hubungan antara konsumsi protein dengan laktosa susu menunjukkan hubungan linier yang positif yang artinya semakin tinggi konsumsi protein semakin tinggi pula laktosa susu.

\section{KESIMPULAN}

Berdasarkan hasil penelitian dapat disimpulkan bahwa terdapat hubungan linier yang positif antara konsumsi protein pakan dengan produksi susu, kadar protein dan laktosa susu. Semakin tinggi konsumsi PK maka semakin tinggi pula produksi susu, kadar protein dan laktosa susu yang dihasilkan kambing PE.

\section{DAFTAR PUSTAKA}

Adriani, A. Latif, S. Fachri dan I. Sulaksana. 2014. Peningkatan produksi dan kualitas susu kambing Peranakan Etawah sebagai respon perbaikan kualitas pakan. J. Ilmiah Peternakan. 17 (1): 15-21.

Arora, R., N. Bhojak and R. Joshi. 2013. Comparative aspacts of goat and cow milk. Int. J. Engineering Sci. Invention. 2 (1): 7-10.
Bath, D. I., F. N. Dickinson, H. A. Tucker and R. D. Appleman. 1985. Dairy cattle : principles, practice, problems, profit. $2^{\text {nd }}$ Ed. Lea and Febiger, Philadelphia.

Devendra, C. dan M. Burns. 1994. Produksi kambing di daerah tropis. institut teknologi bandung press, bandung. (Diterjemahkan oleh I. D. K. Haryaputra).

Herawati. 2003. Pengaruh subtitusi porsi hijauan pakan dalam ransum dengan nanas afkir terhadap produksi dan kualitas susu pada sapi perah laktasi. Sekolah Tinggi Penyuluhan Pertanian, Magelang. Magelang.

Larson, B. L. 1985 a Biosynthesis and celluler secretion of milk. In : B.L. Larson : Lactation, Iowa State University. Ames, $\mathrm{P}$ : 129-163.

Larson, B. L. $1985^{\text {b }}$. Lactation. The IOWA State University Press. Ames.

Marwah, M. P., Y. Y. Suranindyah dan T. W. Murti. 2010. Produksi dan komposisi susu kambing Peranakan Ettawah yang diberi suplemen daun katu (Sauropus Androgynus (L.) Merr) pada awal masa laktasi. Buletin Peternakan. 34 (2) : 94 $-102$.

McDonald, P., R. A. Edwards and J. F. D. Greenhalgh, C. A. Morgan, L. A. Sinclair and R. G. Wilkinson. 2011. Animal nutrition. $7^{\text {th }}$ Ed. Pearson Education, Harlow.

Santosa K. A., K. Dwiyanto dan T. Toharmat. 2009. Profil usaha 
peternakan sapi perah di Indonesia. Lipi Press. Jakarta.

Sidik, R. 2003. Estimasi kebutuhan net energi laktasi sapi perah produktif yang diberi pakan komplit vetunair. Media Kedokteran Hewan. 19 (3) : 135-138.

Soebarinoto, S. Chuzaemi, dan Mashudi. 1991. Ilmu gizi ruminansia. Animal Husbandry Project. LUW-Universitas Brawijaya, Malang.

Sukarini. 2006. Produksi dan kualitas air susu kambing Peranakan
Ettawa yang diberi tambahan urea molases blok dan atau dedak padi pada awal laktasi. Animal production. 8(3): 196-205. Syarief, M. Z dan R. M. Sumoprastowo. 1990. Ternak Perah. CV. Yasaguna. Jakarta.

Wikantadi, B. 1977. Biologi laktasi. Fakultas Peternakan Universitas Gadjah Mada, Yogyakarta.

Yusuf, R. 2014. Kecernaan protein ransum kambing Peranakan Ettawa akibat pembedaan level protein ransum. Bioma. 3 (1): 1-15. 